\title{
W TRANSKULTUROWYM ŚWIECIE EDUKACJI - ANALIZA KOMPETENCJI POLSKICH STUDENTÓW W KONFRONTACJI Z WYZWANIAMI PROGRAMU ERASMUS+
}

\author{
Igor Ganowicz \\ Wydział Psychologii i Kognitywistyki \\ Uniwersytet im. Adama Mickiewicza w Poznaniu, \\ ul. Szamarzewskiego 89AB, 60-568 Poznań \\ e-mail: igogan@st.amu.edu.pl \\ ORCID: https://orcid.org/0000-0003-0800-5669 \\ Wiktoria Moritz \\ Wydział Psychologii i Kognitywistyki \\ Uniwersytet im. Adama Mickiewicza w Poznaniu, \\ ul. Szamarzewskiego 89AB, 60-568 Poznań \\ e-mail: wikmor@st.amu.edu.pl \\ ORCID: https://orcid.org/0000-0003-4726-6597
}

\begin{abstract}
Abstrakt
Teza. Polscy studenci biorący udział w programie Erasmus+, posiadają deficyty w zakresie kompetencji miękkich.

Omówione koncepcje. Opierając się na koncepcji Wrażliwości Międzykulturowej (Bennet, 1998), przeanalizowano wypowiedzi studentów zebrane wśród polskich uczestników programu Erasmus+ pod kątem posiadanych przez nich kompetencji miękkich oraz ich braków, które sami wskazali. Ponadto, korzystając z dostępnych danych dotyczących liczby uczestników programu Erasmus+, wyekstrahowano najważniejsze dla nich umiejętności. Bazując na koncepcji dotyczącej tożsamości kulturowej (Boski, 2010) oraz różnic wynikających z odmiennych kultur, w których europejska młodzież poddaje się edukacji, dostrzeżono potrzebę przeprowadzenia zajęć dokształcających w zakresie kompetencji miękkich polskich studentów.

Wyniki i wnioski. Analiza wypowiedzi, będących inspiracją do podjęcia dalszych działań związanych ze stworzeniem nowych strategii i unikatowego podejścia względem studentów decydujących się na wymianę międzynarodową, wykazała, że zdecydowana większość respondentów nie otrzymała odpowiedniego przygotowania związanego z kompetencjami miękkimi. Jako najbardziej pożądane, respondenci wymieniali takie kompetencje jak: odporność na stres, łatwość nawiązywania relacji/ znajomości czy pewność siebie. Studenci wymieniali również wyzwania, które są dla nich najbardziej wymagające podczas wymiany w innym kraju. Patrząc na wyniki sondy przeprowadzonej wśród uczestników wymiany międzynarodowej oraz da-
\end{abstract}


nych zebranych w grupie kilku tysięcy studentów (Joanna Dąbrowska-Resiak, 2015), można dostrzec nowy obszar do rozwijania, jakim jest deficyt kompetencji miękkich wśród polskich studentów.

Oryginalność/wartość poznawcza podejścia. Zgromadzone informacje i wiedza pozwolą na skonstruowanie warsztatów, dzięki którym będzie można lepiej przygotować polskich studentów do kolejnych edycji programu Erasmus. Korzystając z podejść różnych teoretyków, jak np. Bhawuk, Bennet czy Pinto, można tworzyć warsztatowe formy pracy z młodzieża, dzięki którym poprzez wzbogacenie posiadanych kompetencji będzie można wpłynąć na redukcję stresu wobec wyzwań innego systemu edukacji. Umożliwia to tym samym studentowi bardziej efektywne skupienie się na czerpaniu korzyści z wymiany, ograniczając niepewność i napięcie związane $\mathrm{z}$ brakami w jego kompetencjach miękkich.

Słowa kluczowe: kontekst kulturowy, Erasmus, kompetencje Polaków.

In the transcultural world of education - analysis of the competences of polish students in confrontation with challenges of the Erasmus+ programme

\section{Abstract}

Thesis. Polish students participating in the Erasmus+ programme have deficits in the soft competences as an issue which we need to address.

Concepts discussed. Based on the concept of Intercultural Sensitivity (Bennet, 1998), questionnaires collected among Polish participants of the Erasmus+ programme were analysed in terms of their soft competences and their deficiencies, which they themselves indicated. Moreover, using the available data on the number of Erasmus+ participants and the questionnaires already conducted on the competences of Poles, the most important skills for them were extracted. Basing on the concept of cultural identity (Boski, 2010) and differences resulting from the different cultures in which European youth undergoes education, the need to conduct further education in the field of soft competences of Polish students was noticed.

Results and conclusions. The analysis of the questionnaires showed that the vast majority of respondents did not receive adequate preparation related to soft competences. As the most desirable, respondents mentioned such competences as: resistance to stress, ease of establishing relationships and friendships, or self-confidence. Respondents also mentioned the challenges that are most demanding for them when living on exchange in another country. Analyzing the results, one can see the area of soft competences deficit among Polish students.

Originality/cognitive value of the approach. The information and knowledge gathered will allow for the construction of workshops, thanks to which it will be possible to prepare Polish students more appropriately for the next rounds of the Erasmus programme. Using the approaches of various theoreticians, such as Bhawuk, Bennet or Pinto, it is possible to create forms of workshop to work with young people, thanks to which, by enriching our competences, we will be able to reduce stress before the challenges of a different educational system. This allows the student to focus more effectively on experiencing the benefits of the exchange, reducing uncertainty and tension associated with the lack of soft competences. 
Key words: cultural context, Erasmus+, competences of Poles

\section{Wrrowadzenie - program Erasmus+ w Polsce}

Co roku, na wymianę w ramach programu Erasmus+ wyjeżdża ok. 14000 Polaków. Do dzisiaj, w całym programie wzięło udział już ponad 200000 osób (Dąbrowska-Resiak i inni, 2015). Jak widać, wysyłamy za granicę kolejne pokolenia studentów, mających okazję do nabywania wiedzy w odmiennych warunkach, zarówno tych wynikających z różnic społeczno-kulturowych, jak i tych wynikających z odmiennego podejścia do edukacji i systemu edukacyjnego. Jest to ogromna szansa dla młodych ludzi, którzy stoją u progu swojej kariery, co przyznaje ponad 80\% respondentów (Dąbrowska-Resiak, 2015), uznając wymianę Erasmus+ za przydatne doświadczenie w przyszłej karierze zawodowej. Zgodnie z ogólnoświatowym rankingiem Pearsona (The Learning Curve, 2014), Polska zajmuje dziesiąte miejsce pod kątem zdolności poznawczych (cognitive skills) oraz osiągnięć w edukacji (educational attainment). Świadczy to o dużym potencjale, który posiadają zarówno pokolenia młodzieży, jak i nauczyciele, a szerzej dydaktycy. Skoro tak dobrze Polacy wypadają na tle innych narodów, to warto również przyjrzeć się umiejętnościom innym, niż tylko kompetencje twarde, wynikające z przyrostu wiedzy i specyfiki sposobu nauczania w naszym kraju. Poza tym, program Erasmus + jawi się jako bardzo znaczący element popularnej w dzisiejszych czasach koncepcji Lifelong learning - czyli edukacji przez całe życie. Lifelong learning jest budowaniem umiejętności i wiedzy przez całe życie jednostki (Laal, \& Salamati, 2011). Wiąże się z ograniczeniem wykluczenia społecznego, indywidualnym rozwojem jednostki i większymi szansami na rynku pracy. Edukacja przez całe życie wymaga włączania elementów nauki dostępnych na różnych etapach, tak aby można było je łączyć w jedno. O ile program Erasmus+ zdaje się wypełniać idee edukacji przez całe życie, o tyle nie ma wystarczających narzędzi, aby tę naukę, czerpaną poprzez różne platformy (edukację formalną, nieformalną i pozaformalną) móc wyraźnie zintegrować.

\section{ERASMUS+ OCZAMI POLSKICH STUDENTÓW - ANKIETA BADACZY}

Inspiracją do napisania tekstu były obserwacje grupy studentów wyjeżdżających na wymiany międzynarodowe oraz wypowiedzi, będące wynikiem zadanych pytań. Autorzy zapytali kilkunastu studentów przebywających aktualnie poza granicami Polski w ramach wymiany międzynarodowej, o kilka nurtujących kwestii:

- Jakie aktywności rozwijające Twoje kompetencje miękkie, podjąłeś/aś przed wymianą?

- Czy otrzymałeś możliwość rozwinięcia swoich kompetencji miękkich przed wymianą?

- Z jakimi wyzwaniami wynikającymi z innej kultury i odmiennych form studiowania, spotkałeś/aś się podczas wymiany Erasmus?

Na główne pytanie, które interesowało badaczy, dotyczące poczucia odpowiedniego przygotowanie $\mathrm{w}$ zakresie kompetencji miękkich przed wyjazdem młodych Polaków, aż 76\% respondentów odpowiedziało przecząco. Oznacza to, że zaledwie $24 \%$ uczestników wymian z Polski czuje się wystarczająco przygotowanymi w tym 
zakresie (ankieta przeprowadzona przez badaczy). Autorzy dostrzegają przestrzeń do rozwoju, która powstaje naturalnie w obliczu powyższych danych liczbowych. Podczas doświadczenia, jakim jest międzynarodowa wymiana, każdy z uczestników narażony jest na stres i napięcie, wynikające z czynników takich jak: samotność, poczucie wyobcowania, szok kulturowy (Boski, 2010), czyli konfrontacja z inną kulturą i jej przejawami, np. postawami ludzi, poglądami czy chociażby językiem obcym. Ową przestrzenią jest właśnie praca nad przygotowaniem młodych Polaków do takiego doświadczenia, mająca na celu zredukowanie stresu i umożliwienie skorzystania z wymiany w maksymalnym stopniu. Aby to zrobić, należy dowiedzieć się, jakimi umiejętnościami cechują się polscy studenci oraz z jakimi wyzwaniami mierzą się podczas życia i studiowania poza granicami Polski. Przybliży to tabela 1 przedstawiająca najczęściej udzielane odpowiedzi, na pytanie dotyczące kompetencji innych uczestników wymiany, które respondenci uważają za pomocne i warte nabycia.

Tabela 1

Kompetencje miękkie, które zostały docenione u innych uczestników

\begin{tabular}{|l|}
\hline Odporność na stres \\
\hline Łatwość nawiązywania znajomości/relacji \\
\hline Pewność siebie \\
\hline Umiejętność autoprezentacji \\
\hline
\end{tabular}

Źródło: opracowanie własne

Dostrzegamy tutaj konkretne umiejętności, nad którymi można pracować poprzez formę warsztatową. Badaczy ciekawiło również, w jaki sposób ich rówieśnicy postrzegają posiadane kompetencje - które z nich uznają za cenne, a w związku z czym, które można rozwijać $w$ ramach przygotowań do programu Erasmus+. Zarówno umiejętności już obecne u studentów jak i te, które chcieliby nabyć, mogą być doskonalone lub wykształcane.

Tabela 2

Jakie kompetencje miękkie które posiadasz, uznajesz za pomocne podczas wymiany?

\begin{tabular}{|l|}
\hline Komunikatywność \\
\hline Umiejętność pracy w zespole \\
\hline Asertywność \\
\hline Zarządzanie pracą i czasem \\
\hline Umiejętność aktywnego słuchania \\
\hline Otwartość \\
\hline Umiejętność dostosowania się do nowej sytuacji \\
\hline Łatwość w kontaktach międzykulturowych \\
\hline
\end{tabular}

Źródło: opracowanie własne

W nakreśleniu potrzeb studentów, pomocne stają się wypowiedzi zebrane w ramach sondy przeprowadzonej przez badaczy wśród uczestników programu Erasmus+. W ich (ti. uczestników) ocenie, najbardziej pomocnymi kompetencjami 
miękkimi podczas wymiany są: komunikatywność, umiejętność pracy w zespole, asertywność, zarządzanie pracą i czasem, umiejętność aktywnego słuchania, otwartość, umiejętność dostosowywania się do nowej sytuacji, łatwość w kontaktach międzykulturowych. Dane te korespondują z wymienionymi wyzwaniami, z którymi mogą mierzyć się studenci programu Erasmus+. Są to m.in: braki w edukacji, różne podejście do praktyki i teorii, odmienna mentalność, odmienny sposób sprawdzania wiedzy, odmienność religijna, wyzwania życia codziennego. Z kolei, według danych, zebranych dzięki badaniom grupy ponad 2000 studentów programu Erasmus+, kompetencjami miękkimi, które były rozwijane najbardziej podczas wymiany, są: dostrzeganie wartości innych kultur, znajdowanie rozwiązania w trudnych lub nietypowych sytuacjach, planowanie i samodzielne prowadzenie procesu nauki, planowanie i organizowanie zadań i czynności, współpraca w grupie (Dąbrowska-Resiak, 2015). Biorąc pod uwagę wszystkie dane - zebrane i umieszczone powyżej - można założyć, iż program Erasmus+, oprócz tego, że niesie za sobą ogromne szanse rozwojowe zarówno w sferze rozwoju osobistego, jak i przyszłej kariery zawodowej, jest dla polskich studentów oraz edukatorów ogromnym wyzwaniem.

\section{ERASMUS+ JAKO PROCES ADAPTACJI KULTUROWEJ UCZESTNIKÓW WYMIANY}

W wyjaśnieniu procesu przemian i rozwoju zachodzących podczas wymiany, może pomóc Model Wrażliwości Międzykulturowej (Bennet, 1998), na który składają się poszczególne etapy:

1. Zaprzeczenie

2. Obrona

3. Minimalizacja

4. Akceptacja

5. Adaptacja

6. Integracja

To jeden z wielu modeli związanych z edukacją międzykulturową i świadomym przygotowywaniem do międzykulturowego doświadczenia i wyzwań z nim związanych. Jest on o tyle ważny, iż wskazuje na proces, będący znaczącym elementem doświadczenia, jakim jest dłuższy pobyt w obcej kulturze. Rzadko zwraca się na to uwagę, a może to być kluczowe podczas przygotowań studentów przed wymianą Erasmus+. Wrażliwość na wyzwania związane z doświadczaniem akulturacji studentów, mogą przyczynić się do zmian w postrzeganiu kompetencji, w które należy ich wyposażyć. Ponadto może być początkiem postrzegania procesu akulturacji z wielu perspektyw psychologicznych, a dzięki temu dokładniejszemu przygotowaniu na kilku poziomach: fizycznym, poznawczym, psychologicznym i społecznym. Zaznajomienie studentów wyjeżdżających na wymianę Erasmus+ z procesami, których mogą doświadczać, może przyczynić się do obniżenia poziomu odczuwanego przez nich stresu.

Ważnym elementem zdaje się być również wrażliwość na różnice między krajem ojczystym a wybranym miejscem, do którego wyjeżdżają studenci. O ile jest to doświadczenie praktyczne, którego częścią stają się uczestnicy programu Erasmus+, 
o tyle brakuje wcześniejszego przygotowania na próbę, przed jaką zostają postawieni młodzi dorośli. Brak jest również konsolidacji owego doświadczenia w postaci profesjonalnego podsumowania programu w oparciu o troskę i wrażliwość względem grupy osób wyjeżdżających na wymianę. Wydaje się to istotne ze względu na późniejsze korzystanie ze zdobytego doświadczenia i możliwość lepszego rozwijania owych kompetencji międzykulturowych, kluczowych w XXI wieku. Modelem, który mógłby posłużyć jako pomoc podczas takiego rozwoju, jest chociażby podział zaproponowany przez Geerta Hofstede w pracy Wymiary kultur (Hofstede, 2000). W Polsce- kraju, który otwiera swoje granice i w którym młodzież coraz chętniej korzysta $\mathrm{z}$ ofert wymian międzynarodowych, brakuje odpowiedniego przygotowania związanego z rozwojem kompetencji miękkich. Braki w tej dziedzinie można zaobserwować już od najmłodszych lat, a każdy kolejny etap obowiązkowej edukacji nie zapełnia tych luk na miarę standardów Europy Zachodniej i szans rozwoju przyszłej kariery zawodowej.

\section{ROZWÓJ KOMPETENCJI MIĘKKICH JAKO KLUCZOWY ASPEKT DOŚWIADCZENIA MIĘDZYKULTUROWEGO PODCZAS WYMIANY}

Za cel zmian w formie edukacji, autorzy uznają pogłębianie wrażliwości Polaków na rozwój kompetencji miękkich. Służyć mają temu różnorodne formy. Wśród nich, główny nacisk stawia się na pracę warsztatową oraz pogłębianie zainteresowania edukacją nieformalna, jej odmiennymi formami, chęcią poznania i rozwoju swoich kompetencji miękkich. Ponadto, autorzy stawiają na wydarzenia o charakterze transkulturowym oraz pogłębianie świadomości o powszechności zjawiska, jakim jest transkulturowość. Wydarzenia te powinny być organizowane z zaangażowaniem różnych instytucji, grup społecznych, etnicznych, czy religijnych. Dobrymi przykładami mogą być Warszawski Tydzień Wielokulturowy, Dzień Imigranta (Boski, 2010) czy Europejski Dzień Dialogu Międzykulturowego ${ }^{3}$. Są to wydarzenia, które już się odbywają i które są okazją pogłębiania świadomości transkulturowej oraz praktycznego wykorzystania nabytych już kompetencji przyszłych uczestników wymian.

Jeśli zaś mowa o uczestnikach programu Erasmus+, tu najważniejsze przy rozwijaniu kompetencji miękkich i odpowiednim przygotowaniu się na wyzwania stawiane przez wymianę, jawią się zajęcia o charakterze warsztatowym z obecnymi studentami programu Erasmus+. Ma to na celu zaznajomienie się ze specyfiką programu i grupy osób biorących w nim udział już od samego początku, kiedy to podejmowana jest decyzja o udziale. Warto, aby już wtedy przyszły uczestnik mógł zaznajomić się z posiadanymi kompetencjami miękkimi oraz możliwościami rozwojowymi, jakie daje mu program. Ciekawym rozwiązaniem mogłoby być wspieranie inicjatyw studenckich i zachęcanie studentów do dzielenia się własnym doświadczeniem. Procedura aplikowania na międzynarodową wymianę wymaga czujności, dotrzymywania terminów i kontrolowania wielu dokumentów, które muszą być odpowiednio uzupełniane i składane na czas. Przebiega to w sposób zdezorganizo-

3 https://efil.afs.org/projects-programmes/intercultural-dialogue-day/?fbclid=IwAR0g1aZdE3xXgXZWiJx0HeJ7pvdB4X_cygloerpWrvPdp-SV96KJr_egBnE 
wany i mało komfortowy, czemu można by bardzo łatwo zapobiec, chociażby przez stworzenie krótkiego cyklu wykładów/wystąpień/spotkań, podczas których „doświadczeni" już studenci przedstawią obraz całego procesu i tym samym uspokoją przyszłych uczestników. Nie ograniczy się to tylko i wyłącznie do formalnych procedur, ale też przede wszystkim do charakterystyki kultury oraz stylu życia w kraju, do którego dani uczestnicy będą aplikować (warto wspomnieć o Buddy programme ${ }^{4}$ na Katolickim Uniwersytecie Lowańskim w Leuven, gdzie każdy uczestnik wymiany na podstawie wybranych cech, które są dla niego ważne, może wybrać swojego lokalnego przyjaciela, który podzieli się z nim doświadczeniami, zaoferuje pomoc w szukaniu mieszkania, a przede wszystkim wprowadzi w rytm i styl lokalnego życia!). Dzięki stworzeniu takiego cyklu lub cyklów (uwzględniając podział na różne kraje docelowe), polscy studenci już przed wymianą będą mieli konkretną dawkę wiedzy opartą na doświadczeniu, przez co nie będą całkowicie nieprzygotowani na nową sytuację. Korzyści płynące z tego rodzaju aktywności są obopólne - „eksperci przez doświadczenie", bo tak można by nazwać studentów po wymianie, rozwijają swoje kompetencje miękkie poprzez przekazywanie wiedzy, odpowiadanie na pytania i przekładanie swoich doświadczeń z obszaru wspomnień i doświadczeń na realne porady i wskazówki, tym samym pomagając przyszłym uczestnikom wymiany. Co nie powinno zostać pominięte, to fakt, że wiele osób nie decyduje się na wymianę z powodu szeregu obaw, które skutecznie je przed nią powstrzymują. Jedną z głównych przyczyn są lęk przed tym, że uczestnicy nie poradzą sobie w tak odmiennych warunkach, to że będą tam sami i odcięci od swoich bliskich oraz strach przed komunikacją w języku obcym (przyczyny zaobserwowane przez badaczy). Dostarczenie odpowiedniego przygotowania dla tej grupy mogłoby wpłynąć na tak ważną decyzję, jak udział w samej wymianie. Zakładamy, że studenci mając samą tylko świadomość tego, że nie zostaną pozostawieni sami sobie w całym procesie przygotowania, mało tego, zostaną „zaopiekowani”, a uczelnia zadba o ich komfort, mogą zmienić swoje podejście i skorzystać z niepowtarzalnej szansy, którą oferuje Erasmus+ i nasze polskie uczelnie. Dlatego jeśli byśmy połączyli wspieranie studentów przed wymianą w rozwijaniu ich kompetencji miękkich, poprzez wspólny trening kompetencji, zachęcanie do brania udziału w inicjatywach społeczno-zespołowych lub na przykład program mentoringowy z cyklem akulturacyjnym tworzącym przestrzeń do wymiany doświadczeń oraz redukowania niepewności i strachu, to moglibyśmy znacząco wpłynąć na komfort i dystres przyszłych uczestników nie tylko programu Erasmus+, ale również innych form wymiany międzynarodowej. Poza kompetencjami miękkimi dużą rolę odgrywa również język obcy, o czym wspominają rumuńskie badaczki (Coroamă- Dorneanu i Urlica, 2018).

Warto wspomnieć również o tym, że dla niektórych studentów możliwość przeżycia czegoś niespodziewanego, nieznanego czy dotąd niedoświadczanego, może być kluczowym czynnikiem skłaniającym do wzięcia udziału w wymianie. Dlatego też propozycja badaczy jest skierowana do tych osób, które chciałyby wziąć udział w takim procesie przygotowania, oczywiście o nieobowiązkowym charakterze.

$4 \quad$ https://www.kuleuven.be/english/studentservices/pangaea/buddy-programme 


\section{DośWIAdCZENIE MIĘDZYKULTUROWE JAKO PRAKTYKA LIFELONG LEARNING - KIERUNEK DALSZYCH BADAŃ I DYSKUSJA}

Atrakcyjnym podejściem do życia i doświadczania, może być wspomniana wcześniej perspektywa Lifelong learning, czyli uczenie się przez całe życie. To stosunkowo młody trend, rozumiany jako: całość aktywności poznawczych podejmowanych w trakcie życia z myślą o pogłębianiu wiedzy, umiejętności lub kwalifikacji (z przyczyn osobistych, społecznych lub zawodowych) (Tissot, 2004). Podążając tym sposobem myślenia, odpowiednia interpretacja własnych doświadczeń może wzbogacić naszą perspektywę spostrzegania rzeczywistości, a zarazem pozwolić na docenianie i wykorzystywanie zgromadzonych uprzednio, jak i na bieżąco przeżywanych doświadczeń. Wydaje się, że im bardziej świadomie wymiana i międzykulturowe doświadczenie postrzegane będzie jako ważny moment, składowy element naszego życia, tym łatwiej będzie jednostce wykorzystać go jako swój kapitał na przyszłe, dorosłe życie. Jednakże pomimo optymistycznego nastawienia badaczy, nie wykazano jasnej zależności pomiędzy nastawieniem na uczenie się przez całe życie a poziomem szczęścia jednostki, o czym piszą naukowcy z Cambridge (Narushima, Liu i Diestelkamp, 2018). Autorzy niniejszej pracy uważają jednak, że może być to nowy kierunek badań, który mógłby znacząco wpłynąć na perspektywę przeżywania wymian międzykulturowych, a w tym przypadku wymiany w ramach programu Erasmus+.

Nie powinno się jednak pomijać faktu, który powinien być stopniowo coraz bardziej dostrzegany, mianowicie nie wszyscy studenci są na tyle mobilni, aby wyjeżdżać na zagraniczną wymianę. Możliwa jest natomiast zmiana dotychczasowego sposobu przeprowadzania zajęć i umożliwienie niemobilnym studentom nabywania zdolności językowych i kompetencji międzykulturowych na ich rodzimych uczelniach - tak konkludują węgierskie badaczki (Németh, Marek, Hild i Csongor, 2020). Skoro badacze zakładaja, że można w ten sposób rozwijać kompetencje językowe i kulturowe, to zarazem można rozwijać kompetencje miękkie, które mają wiele wspólnego z kompetencjami międzykulturowymi. Zdolność do przyjmowanie perspektywy innej osoby, zdolność do przybierania relatywistycznej postawy wobec świata czy myślenie abstrakcyjne w rozwiązywaniu problemów to tylko jedne z wielu kompetencji, które wpisują się w obszar zarówno miękki jak i międzykulturowy. Jest to ważne spostrzeżenie $\mathrm{w}$ perspektywie dalszej analizy kompetencji studentów biorących udział w programach wymian międzynarodowych.

\section{Podsumowanie}

Przytoczone formy są odpowiedzią na niezagospodarowaną przestrzeń, jaką pozostawia polski system edukacji i pojawiające się możliwości, związane z rozwijającą się międzykulturowością. Obecnie funkcjonujący system zdaje się nie przynosić oczekiwanych korzyści i sam w sobie może odpowiadać założeniom Lifelong learning, jednak w dobie globalizacji i międzykulturowości, bez świadomej konsolidacji tego doświadczenia, będzie ono tylko jednym z wielu międzykulturowych przeżyć, a nie świadomym doświadczeniem, które można przerodzić w szeroki rozwój indywidualny. 
Zaproponowane formy, same w sobie są jednak tylko bazą którą można pogłębiać i -poddawać kolejnym analizom. Głównym celem było wskazanie obszaru, jakim jest brak nacisku na rozwijanie kompetencji miękkich wśród młodych ludzi, potrzeba ich wspierania oraz kilka propozycji i pomysłów na to wsparcie w kontekście lepszego przygotowania do międzykulturowych i międzynarodowych doświadczeń polskich studentów.

\section{Bibliografia:}

[1] Boski, P. (2010). Międzykulturowe ramy zachowań społecznych. Warszawa: Wydawnictwo Naukowe: PWN.

[2] Dąbrowska-Resiak, J., Jeżowski, M., Koźbiał, E., Łaboda, I., Miłoń, E., Nowacka, A., Pachocki, M., Piekarska, M., Szwałek, K., Wojciechowski, T. (2015). Raport 2015. Warszawa: Fundacja Rozwoju Systemu Edukacji.

[3] Bennet, M. (1998). Podstawowe koncepcje komunikacji międzykulturowej. Wybrane teksty. London: Intercultural Press.

[4] Coroamă- Dorneanu, L-I., Urlica, A-A. (2018). The language class, an environment for developing soft skills [Zajęcia językowe jako środowisko dla rozwoju kompetencji miękkich]. Research Journal of Agricultural Science, 50 (4), 87-90.

[5] Hofstede, G. (2000). Kultury i Organizacje. Warszawa: Polskie Wydawnictwo Ekonomiczne.

[6] Narushima, M., Liu, J., Diestelkamp, N. (2018). Lifelong learning w dyskursie dotyczącym starzenia się: pozytywny efekt, wpływający na samopoczucie, zdrowie i wrażliwość. Ageing and Society, 2018, 651-675. Cambridge: University Press.

[7] Laal, M., Salamati, P. (2011). Lifelong learning; why do we need it? [Uczenie się przez całe życie; po co nam to? ]. Procedia - Social and Behavioral Sciences 31 (2012) $399-403$.

[8] Németh, T., Marek, E., Hild, G., Csongor, A. (2020). Rozwój kompetencji międzykulturowych i językowych wśród studentów poprzez program Erasmus: wnioski oraz wprowadzone zmiany systemowe. Journal of Languages for Specific Purposes, $7^{\text {th }}$ Issue, March 2020 57-68.

[9] Tissot, P. (2004.) Terminologia zasad kształcenia zawodowego. Wielojęzyczny stowniczek dla rozszerzonej Europy. Office for Official Publications of the European Communites, Luxembourg. 